\title{
Design Concept Integration Tax Payment System with Implementing Financial Technology
}

\author{
Mihuandayani \\ Magister of Information Engineering, Universitas AMIKOM Yogyakarta, Indonesia \\ Email: mihuandayani20@gmail.com \\ Ema Utami \\ Magister of Information Engineering, Universitas AMIKOM Yogyakarta, Indonesia \\ Email: emma@nrar.net
}

Received: 02 February 2018; Accepted: 06 August 2018; Published: 08 September 2018

\begin{abstract}
Taxation has an important role as state revenue in the State Budget. In 2017, the target of tax revenues in the State Budget is about Rp. 1,498.9 trillion so that the Ministry of Finance of the Republic of Indonesia contrives as well as possible through the fiscal policy reform to fulfill the targets. One of the efforts which undertaken by the Directorate General of Taxes is applied tax payment system using e-billing with the electronic deposit slip. E-billing (electronic billing) is an online service which uses the system through the issued code on a kind of tax payment. The tax payment system is based on self-assessment to make deposits or tax payments independently by the taxpayer. Developments in technology influenced the emergence of innovations particularly financial technology in the finance industry. An industry which worked in the finance sector utilizing financial technology in the payment system. This kind of condition can provide opportunities for financial transaction service electronically. In this research proposed a tax payment system design which can be integrated with financial technology industry through Service Oriented Architecture (SOA) approach. The design which included in this paper is technology architecture, data modeling, use case diagram of service and system integration design. A conceptual design is realized as an effort to utilize financial technology to provide alternative tax payment transactions in achieving the target of state revenue.
\end{abstract}

Index Terms - Integration Design, Tax Payment, ebilling, Financial Technology, Service Oriented Architecture.

\section{INTRODUCTION}

The objective of taxation is how to increase the economic development. The economics of a country is depended on the growth of capital management. In State Budget 2017 of Indonesia, the government still relies on taxes as the main support of national income. Taxes contribute to about $85.6 \%$ or Rp.1, 498 Trillion of all state revenue [1]. Apart from taxes, state revenue came from the administration of non-tax state revenue as well as grant revenue from domestic and international that contribute to the State Budget.

According to the Law No. 16 of 2009 concerning the fourth amendment to the Law No. 6 of 1983 concerning General Provisions and Tax Procedures in Article 1 paragraph 1, tax is a compulsive contribution to a country which owed by an individual or entity which is forcefully based on the Law, without getting direct benefits and being used for the purposes of the country for the greatest prosperity of the people. Based on the definition of a tax, incoming tax money in the state treasury, it has not directly felt by the public or taxpayers. The tax money is allocated in economic development to support the wheels of government. Distribution of tax money from the State Budget or APBN through the approval of the government and the House of Representatives (DPR) is managed for infrastructure development such as roads, bridges and public facilities. In addition, taxes are used for general allocation funds, health services, education services, public transportation, defense and state security systems, food subsidies, fuel subsidies (BBM) and so on.

In Indonesia, taxation is managed by government agencies, namely the Directorate General of Taxes under the auspices of the Ministry of Finance of the Republic of Indonesia. In carrying out its duties and responsibilities, the Directorate General of Taxes has an obligation to foster, serve and supervise the public related taxation imposed on taxpayers. Appraise from the sources of tax collection agencies are generally differentiated into Local Tax and State Tax. Based on statistic data from the Directorate General of Taxes official website, the tax compliance reporting ratio of SPT reaches about 54.54\% of Taxpayer consisting of Taxpayer Agency, Taxpayer Non-Employee Personal and Taxpayer Employee [2]. Taxes imposed on such Taxpayers as income tax (PPh), Value Added Tax (VAT), Sales Tax on luxury goods (PPnBM), stamp duty, Land and Building Tax (PBB) and other local taxes.

The condition of tax compliance based on the data, it still became a matter of taxation about the low of awareness and understanding of how important in paying 
taxes. In addition the processes of bureaucracy in the payment of taxes, as well as the existence of certain elements that utilize taxes for inappropriate intention. The government has continued to make efforts to the public, especially in order to fulfill the state budget target of taxation. Efforts undertaken by the Directorate General of Taxation include the implementation of a tax amnesty program or a taxpayer elimination program consisting of tax payable, administrative sanctions and tax penalties which have not been reported in the Notice Letter (SPT) by paying the tax arrears and ransom payments.

Currently, the development of technology provides ease, especially in financial technology, including in making tax payments. Financial technology innovation known as Fintech is able to change the financial business model through various features integrated into the information system. This combination of technology and finance is a phenomenon that fosters inclusive finance. In connection with the tax payment process, the tax payment system in Indonesia has evolved by starting from direct payments in the State Treasury Office, then developing payments through Banks known as the Bank of Perceptions and further banking began to utilize the information system of the Online Banking System using online banking facilities which called Government Revenue Module (MPN).

Today the tax payment system implemented since July 1st, 2016 is through Government Revenue Module of the Second Generation (MPN-G2) which uses e-billing and e-filling system. E-billing is a payment system that uses electronic media and facilitates the issuance of billing codes for tax payments. Some of the benefits which can be felt in the use of MPN-G2 tax system is the application to calculate PPh, VAT, e-billing, e-invoice, and e-filling in one application. So the user does not need to input the same data repeatedly. Besides, this system in the level of accuracy can minimize the manual transaction logging errors because it can automatically fill in Tax Account Code and Deposit Type Code. Then, the existence of realtime transactions directly recorded in the system of the Directorate General of Taxes and the state treasury. In addition, it can generate billing codes for other NPWPs at once. NPWP means the taxpayer identification number which has by the taxpayer in doing the tax payment.

The collecting agent such as Banking and Post have taken advantage of e-billing services to support the tax payment system. This system to be further reviewed can provide opportunities for financial technology companies to take part in efforts to improve tax-abiding society. The existence of Fintech is available on the basis of Regulation of Financial Services Authority (POJK) Number 77 / POJK.01 / 2016 on lending and borrowing services. To be able to connect the tax payment business process can be done through the integration of the ebilling system with the financial technology industry. The existence of various alternatives for tax payments increasingly provides an opportunity to pay for taxpayers by supporting financial technology innovation. So that all layers of society or taxpayers can feel the ease of facilities in making tax payments. In carrying out system functions in such cases, it requires system integration among different information systems of back office system activity. Systems that can link the performance of the e-billing system with its outer system. To solve this problem, a technology architecture model is required by approach and methods for information system integration. The approach used in this research is Service-Oriented Architecture (SOA).

SOA has become a trend where it has been applied to several different domains such as robotics, healthcare, and e-governance portal [3]. Service Oriented Architecture (SOA) is a software architecture which is built using principles in service-oriented design. Meanwhile, by another definition, Service Oriented Architecture (SOA) is a style of developing and integrating software [4]. A primary goal of using SOA to simplify payments is to enable banks to reconfigure existing IT assets when new assets or customer demands arise potentially avoiding the need to build or purchase new applications.

In this research proposed a model of architecture design based on Service Oriented Architecture (SOA) which integrates e-billing system for tax payment system in Indonesia with the financial technology industry. The resulting integration model aims to connect the tax payment system through the ease of financial transactions utilizing Fintech. With the proposed model is expected to assist the Directorate General of Taxes to fulfill the target of state revenue from taxation.

\section{RELATED WORD}

In this study refers to the references related to the methods used in integrating the system with Service Oriented Architecture (SOA) approach and technology utilized in the implementation of financial technology.

A research reference which worked to integrate two enhancements using the Service Oriented Architecture (SOA) and to connect the Consumer Service (SC) and Service Provider (SP). It aims to create services in complying consumer needs in the mobile web service verifier component. Increased mobility of SOA which used Service Upgrade (SU) has the ability to acquire Service Providers for required services and deliver new services to Consumer Services when mobile web service verifiers do not have appropriate services. The study shows that the majority of respondents support with a percentage of $49.04 \%$ in the validation of the proposed SOA architecture questionnaire through qualitative data [5].

The research proposed Service Oriented Architecture (SOA) integration based on Web Services for government systems. The case study in that research is the environmental license web service at Jordan's environment ministry and also this system integration is intended because the Jordanian government demands collaboration and facilitation between the private sector and non-governmental organizations (NGOs) in providing services to its citizens [6]. 
Another research reference discussed dependency analysis in SOA. The purpose of this study is to get a view of the coherence of the aspects in the architectural style and programming paradigm on the use of SOA. Under this system, software service has a dependency on other software services in providing and receiving relationship [7]. Understanding SOA-based system dependencies there are two functions: impact analysis or understanding with the various components that affect when a component is not working properly and dependency about software component root cause analysis or understanding the cause of the component by analyzing at the dependencies of other components [8].

The study discussed the application of a combination of Service Oriented Architecture (SOA) and Web Service to provide efficient integration and service with new concepts. This allows the organization to add new, standard-grained, abstract layers, easy to integrate with a new system and existing systems to make it easy to build new concepts of existing services. The use of SOA with this service can reduce costs, reduce the amount of code, and reduce management [9]. Web services are a challenge in handling issues of information systems integration. The importance of privacy in accessing web services is necessary to maintain service interaction. However, in the absence of techniques which worked to reduce the credentials in interaction system such as negotiation for credential generalization and substitution between consumers and providers. In this case, the research discussed an approach for web service privacy preserving with some approach namely negotiation, encryption, and certificate authority 'as the third party. It was found that the new approach had a minimum privacy disclosure for web service interaction [10].

International journal which discussed the maturity model in the use of service-oriented architecture (SOA) used to provide and define SOA in an organization. By comparing the maturity model of SOA based on maturity level, evaluation dimensions, and evaluation method. It found the conclusion about to build maturity level is done by adapting the identified level in adopting innovation concept, SOA also must be reviewed from the perspective of business and treated from both information technology [3]. The research is related to the promised benefits that SOA provided such as flexible reconfiguration and reducing the development cost have attracted many organizations to adopt SOA [11].

In the healthcare sector, Service Oriented Architecture (SOA) is implemented by introducing SOA concepts and identifying the key features. Such research focused on developing SOA-based home healthcare systems. The study discusses in terms of functionality, security analysis, and semantic operability by proposing an architecture with two subsystems: the subsystem is located in the patient's home and the subsystem located in the clinic or health care provider [12]. Other journals related to this research are the integration point of sale terminal with the financial institution. The journal focused on Web Service utilization using SOAP as a file process from the vendor's web server to the financial institute. In this journal shows that the transaction through web services can become competitive. The research method, in this case, uses an approach from Burstein and Gregor as it presents a method of group research [13].

\section{RESEARCH METHODOLOGY}

The method which is used in this study to be started with the stages of identifying taxation issues such as tax functions, applicable laws, targeted amounts of state revenue through taxes, problems occurring in tax payments, and the implementation of the current system of tax payments. The steps in this research can be shown in Fig.1.

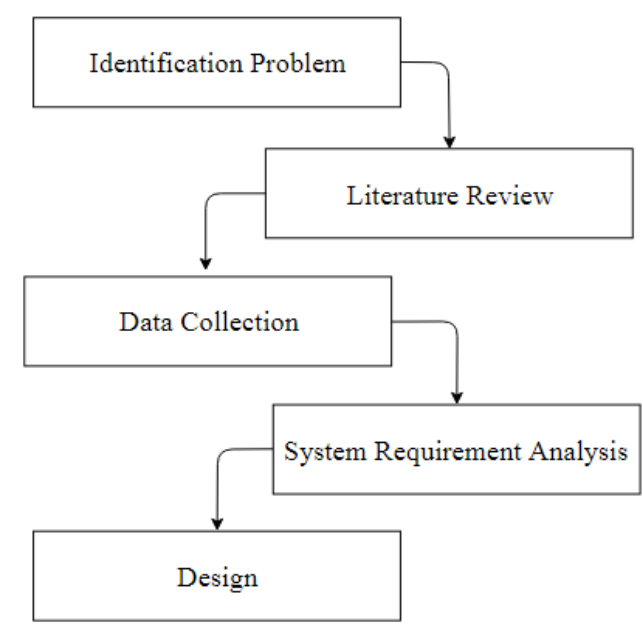

Fig.1. Research Stages

In addition to identifying problems in the taxation, this study also identifies opportunities that can be proposed as a support in the tax payment system. The opportunity is about alternative ways to pay taxes. Currently, the system has been applied is focus on e-billing system. In the system, access to tax payments after creating the billing code is payments through the Bank or Post Perception. Payment via Bank can utilize the service in teller or counter Bank, ATM machine, Mobile Banking and Internet Banking.

This research proposed the existence of opportunities which can be utilized in financial transactions. The development of technology to create ease and innovation in the field of finance, one of which is the application of financial technology that serves to change the system of payment in cash into a cashless payment. This innovation was developed to realize inclusive and more transparent finance and facilitate access to payments. Several studies on the use of financial technology have been conducted as in the journal [14] which utilizes payment transactions for cooperative members and connects third parties as payment providers.

According to the study of Thomas F.Dapp that financial technology is a catchall used for advanced, mostly internet-based technologies in the financial sector [15]. The scope of developed financial technologies such as Crowdfunding, Peer to Peer (P2P) Lending, and 
Payment and so on. In this case, utilization is used in the Fintech business industry that moves specifically to carry out payment transaction processing. Furthermore, the research stages are literature study. This literature study includes a study of methods used for the development of systems integration. Understand the basic concepts and planning of a model to integrate the system. The selected integration model adapts to the system requirements. Then determine the most appropriate integration model and allows to be able to process and manage the systems that will be integrated.

The integration model used in this research is based on Service Oriented Architecture (SOA). Where the SOA development method used is the Service Oriented Modeling and Architecture (SOMA) method. SOA is a system development methodology which can move dynamically when developing an information system. Many things can be reduced in operating a process on SOA, making it easier and faster to do a job. Something that does not need to be done over and over again, for example, someone checks, stores, or gets a medical record when only interact with validation and the same data. Building applications with the same source will be easier and faster for interconnected companies.

Service Oriented Architecture is an information system architecture that packs some parts of the application architecture as a service [16]. SOA provides a design framework with a view to rapid realization with little cost of system development to improve system quality. Based on research [17], the Service Oriented Architecture framework may be regarded as seven layers architecture successively from the bottom-up level ie, Operational systems layer, Enterprise components layer, Service layer, Business processes layer, Access layer, Integration layer and Management and security layer.

After conducting a review literature related to Service Oriented Architecture (SOA) approach, data collection is done related to the integrated system. The collection of data means the collection of data by the end-user side such as the need in issuing billing code, data for charging tax payment forms and identifying the data needed in integrating e-billing system with Fintech industry in terms of payment. The next necessary step is to perform a system requirement analysis based on the identification of the problem that has been done. System requirements analysis is described as a feature which enhances system functionality. Requirement analysis on the Fintech industry side and from e-billing system side. This is related to the data as a requirement of the system to be integrated with the electronic billing. In addition, need to understand the technology to be used in the development of Service Oriented Architecture (SOA). After analyzing the requirements system needed to do the design phase. The design is composed of technology architecture design with SOA approach, data model design, design use case diagram and service as well as service integration architecture which will be discussed further in the result and discussion section.

\section{RESULT AND DisCUSSION}

The discussion in this section included the results of identifying a problem by knowing the business processes occurred such as system requirements analysis, the design of technology architecture, data modeling, use case diagram, service use case and the design of service integration through Service Oriented Architecture (SOA).

\section{A. Business Process}

The tax payment system in Indonesia has used the Government Revenue Module with e-billing system. In general, the business processes proposed in this study can be shown in Fig. 2.

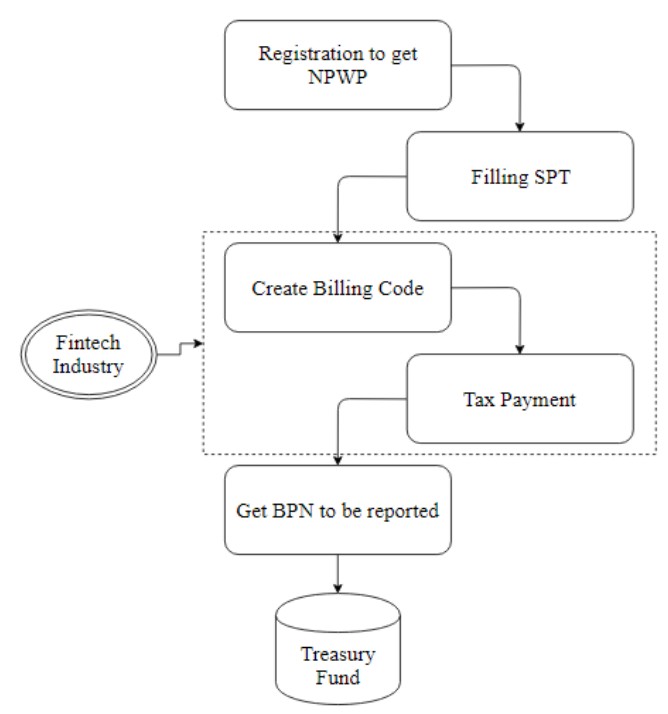

Fig.2. Business Process

E-billing system which managed by the Directorate General of Taxes has been linked with several banking services including local banks. Taxpayers are currently required to use e-billing facilities in the tax payment mechanism. The business process in taxation is made by the taxpayer who meets the subjective and objective requirements of registering at the Tax Office to obtain NPWP. Then Taxpayer must fill SPT or Tax Return by self-calculate all the taxes charged. Furthermore, the tax mechanism focused on this research is in the process of tax payment. In this stage includes the creation of billing and payment codes. Taxpayer performs the billing code through e-billing system by completing the Tax Account Code) and Deposit Type Code first through the form of the application. Then, the billing code will be sent via user email. After creating a billing code, the taxpayer should do the payments transaction through a bank account. When the nominal amount of the balance is sufficient to make the tax payment, the money transfer will be done. Make a confirmation of tax payment through the application to display a successful message in the successful transaction data. In this study intended to connect a system of the financial technology industry in 
tax payment with e-billing. System integration through web service can be done through Service Oriented Architecture (SOA) approach. With this integrated system, users can make tax payments through accounts held in the Fintech industry by top-up balances without a need to have bank account first. This stage is also designed to be used on Personal Computer, laptop or mobile phone connected internet. After that, the Taxpayer will get a Proof of State Receipt as a note or proof of transaction to be reported. The financial transactions that have been made will be recorded into the state treasury and managed as State Budget or State Revenue Budget and through the approval of Parliament used for the benefit of the community. The difference in the existing business process with the proposed business process that there is a financial technology industry in managing the payment process. Based on the business proposed, Analysis of system requirements for users can be explained in the following Table 1 .

Table 1. System Requirements

\begin{tabular}{|c|l|l|}
\hline No & Requirements & \multicolumn{1}{c|}{ Explanation } \\
\hline 1 & $\begin{array}{l}\text { The system can } \\
\text { publish the } \\
\text { billing code }\end{array}$ & $\begin{array}{l}\text { After filling SPT, user can create } \\
\text { billing and then billing code can be } \\
\text { published }\end{array}$ \\
\hline 2 & $\begin{array}{l}\text { The system can } \\
\text { manage the } \\
\text { payment } \\
\text { transaction } \\
\text { process }\end{array}$ & $\begin{array}{l}\text { The payment process is done through } \\
\text { account on the Fintech industry by a } \\
\text { top-up balance then Taxpayer } \\
\text { confirms the payment in application }\end{array}$ \\
\hline 3 & $\begin{array}{l}\text { The system can } \\
\text { perform NTPN } \\
\text { validation }\end{array}$ & $\begin{array}{l}\text { The system may conduct verification } \\
\text { throught Taxpayer } \\
\text { transaction }\end{array}$ \\
\hline 4 & $\begin{array}{l}\text { The system can } \\
\text { transmit in the } \\
\text { form of BPN }\end{array}$ & $\begin{array}{l}\text { After verification of payment is done, } \\
\text { the system sends note of transaction } \\
\text { in the form of BPN through Taxpayer } \\
\text { email }\end{array}$ \\
\hline
\end{tabular}

Identifying problems with this business process is needed to analyze the needs of data exchange and to integrate applications which have different platforms. Payment data managed by the Fintech industry and must be integrated with the e-billing system. This integration worked with the business or industry Fintech in the payment system in order to perform data management efficiently. Therefore it takes a plan in the form of architectural design through Service Oriented Architecture (SOA) approach. The financial technology industry is connected to the process of paying taxes and create billing. The system requirements which analyze in this research means for system requirements by users in integrating the system. The system must be able to integrate the e-billing system with Fintech industry according to its function. Exchange or transfer data contained in the system must also be done properly and efficiently in accordance with the needs of business processes.

\section{B. Design of Technology Architecture}

In the design of technology, architecture describes the relationship between systems which are integrated into the web service. The technology in the Service Oriented Architecture approach has several advantages and disadvantages. The technology is described as BPEL (Business Process Execution Language) and RESTful as the best standards in the SOA approach [18]. This research used REST technology to improve the quality of network services. It showed as part of the architecture and a secure service [19]. In this research, the Payment Service Provider has its own server for the process of the transaction. Besides that, Biller and Settlement also can connect each other through the server. The design of technology architecture can be shown in the following Fig. 3.

\section{Data Modeling}

To be able to design an integration between two or more systems, it is necessary to identify the main system to be used as a guide so that other systems to be integrated must adapt the data model to the main system. In this study, e-billing is the main system and the system in the Fintech industry which is integrated can adjust the data model of the e-billing system. Required data transfer such as taxpayer data, data of deposit code, data of tax account code and payment account data in order to model the data integration for publishing billing code and payment transaction.

For publishing the billing code and payment transaction needed to define detail data such as the identity of the taxpayer which has NPWP, characteristic of tax account code which has a unique number and deposit code based on the kind of valid tax. This kind of requirement data has been available in the e-billing system database and should be integrated with Fintech industry system. After knowing the requirements data to transfer into e-billing system and Fintech industry system, made a relational data such as class diagram to understand the flow of data based on the entity. The design of data modeling can be shown in the following Fig. 4.

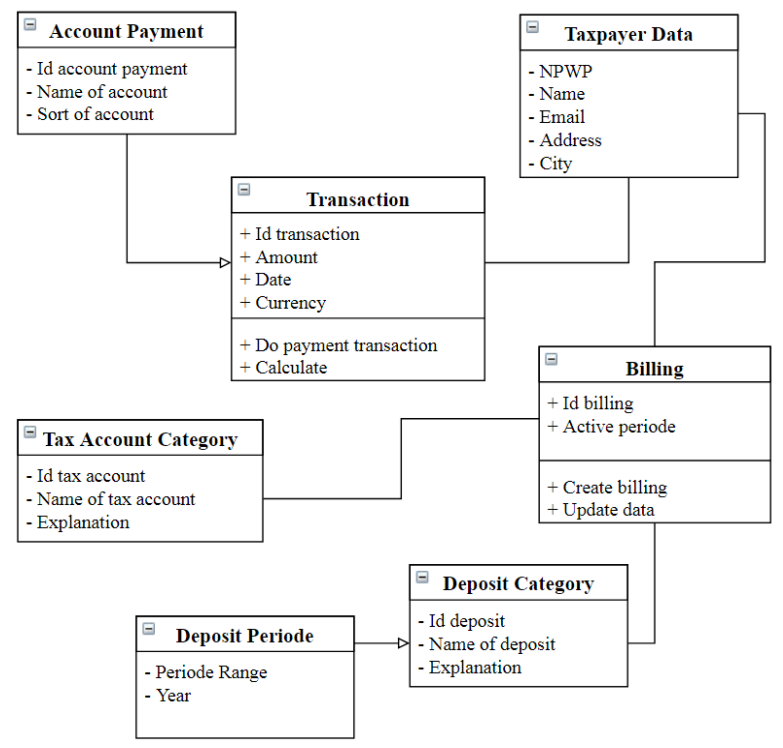

Fig.4. Data Modeling 


\section{Use Case Diagram}

System integration involves stakeholders who are specifically users of the system. Actors who play a role in systems integration in this study are Taxpayer, Biller, Settlement and Payment Provider. Every actor has their own role in the integration system. This use case included the web service in the payment process by doing of the taxpayer. Through the web service, the system is allowed to do a transaction with transfer data into the payment provider.

The detailed role of actors can be explained as follows the Taxpayer is required to create billing and do the tax payments, Biller as the user who issued the billing code and by system will send the billing code, Settlement as part of the system which verifies the compliance of tax payments in the form of NTPN and send the notification to the taxpayer, Payment Provider as a third party in this case Fintech industry which linked through system integration and have the responsible for managing payment transactions process after getting the validated NTPN and submit the note of transaction which is done by the taxpayer in the form of BPN. The following Fig. 5 shows the use case diagram in the integration pattern of this study.

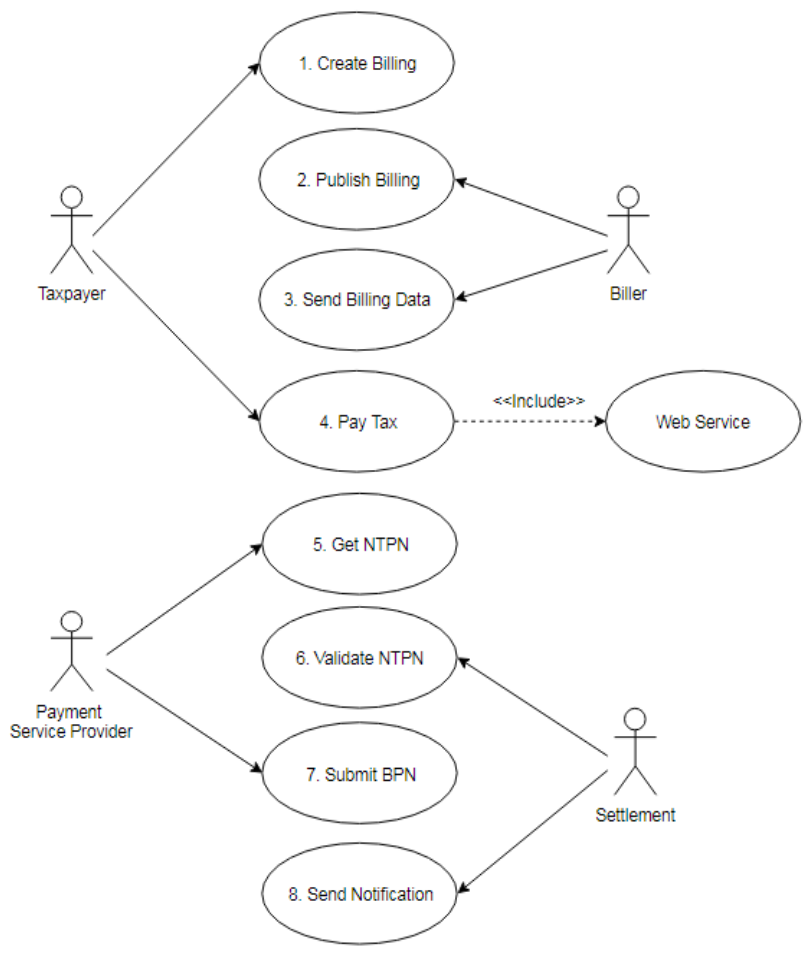

Fig. 5. Use Case Diagram

\section{E. Design of Service Use Case}

The design of service use case needs an understanding in knowing the scope of services built and integrated. It aims to facilitate the general view of interactions that occur from interconnected services. The design of this service use case is illustrated in Fig. 6.

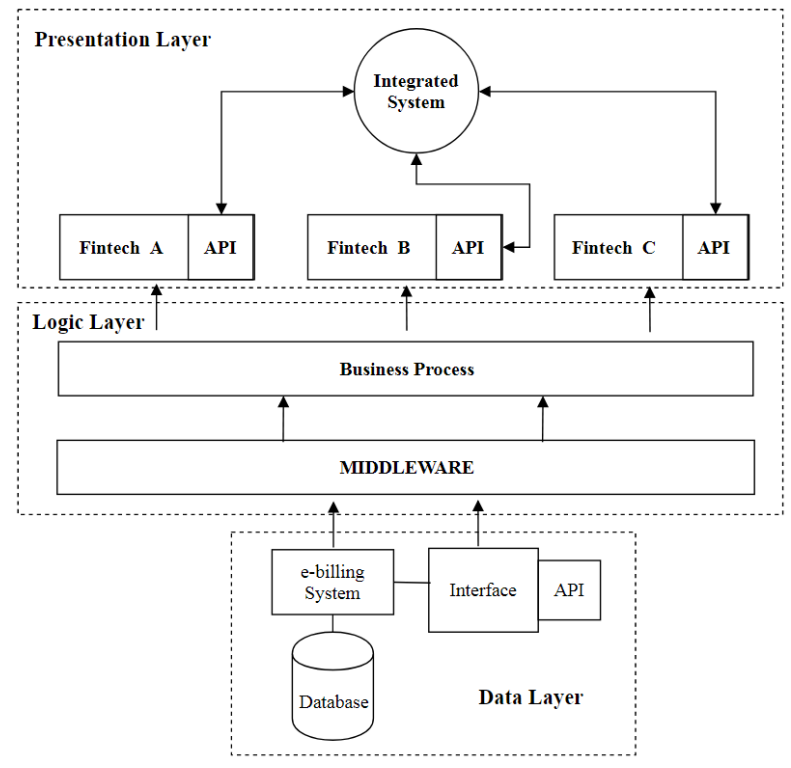

Fig. 6. Service Use Case

Through an integrated system in the presentation layer, systems in the Fintech industry can be interconnected via middleware with e-billing system that has a major database. In the data, layer described the e-billing system with the database and interface. The logic layer here means the process of the integrated system based on the business process.

\section{F. Design of Integration System}

In the design stage of system, integration architecture required steps to understand the layer of Service Oriented Architecture (SOA) approach. In this research, the integrated system architecture model with Service Oriented Architecture (SOA) approach in the case of ebilling system with Fintech industry is modeled with Fintech System A, Fintech System B and Fintech System C. This architecture model using middleware through web service with REST technology capable of implementing strategies to communicate the applications of the agency. This service-oriented architecture made the level of service interface which can be presented in general. Web services technology provides a way in transactions, so the application can run efficiently in connecting the interface in the designed application. Tax payment system through various applications such as web application, mobile application, ATM machine and Teller Bank or Post Perception. Then through the presentation layer like a web browser, Fintech System as the third party integrated with Tax Payment System through web service can transfer the required data from source database owned by Tax Payment System. The integration described using REST technology to connect and communicate with existing systems. The design proposed in this paper is planned to be implemented for e-billing that has been made available by Directorate General of Taxation by linking to the tax payment system in Indonesia through the cashless payment industry that has applied financial technology. The system integration architecture can be shown in Fig. 7. 


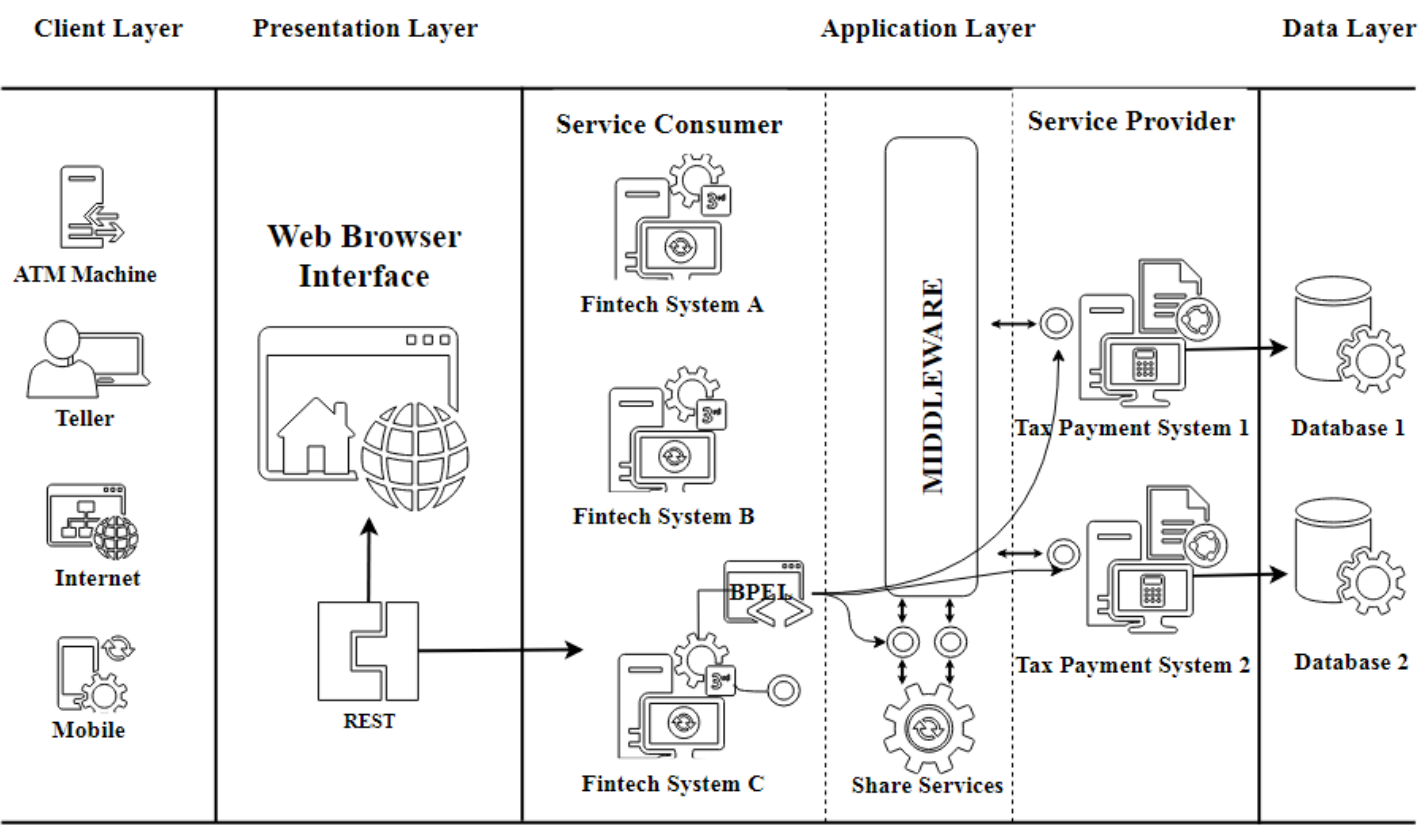

Fig.7. System Integrated Architecture

\section{CONCLUSION}

The conclusion resulted in this research is in the form of an architectural design model which integrate tax payment of e-billing system with the payment system in the financial technology industry. Design model used in this research is the Service Oriented Architecture (SOA) approach to REST technology. The design included the form of technology architecture design, data modeling, use case diagram and service use case as well as system integration architecture.

\section{ACKNOWLEDGMENT}

Universitas AMIKOM Yogyakarta for the support by giving all the facility which is needed for the study. This research also can be done by a good cooperation among all sector and big effort to provide a paper which hopes can be useful for others.

\section{REFERENCES}

[1] Admin. (2017, October 15), State Revenue Realization Ministry of Finance of the Republic of Indonesia. Available online: www.bps.go.id

[2] Admin. (2017, October 17), Reporting Compliance Ratio of SPT - Directorate General of Taxation. Available online: www.pajak.go.id

[3] Mohd Hamdi Irwan Hamzah, Fauziah Baharom, \& Haslina Mohd. (2017). A conceptual model for serviceoriented architecture adoption maturity model in Zulikha, J. \& N. H. Zakaria (Eds.), Proceedings of the 6th International Conference of Computing \& Informatics (pp 139-145). Sintok: School of Computing.

[4] Jay DiMare and Richard S. Ma. 2009. Service-Oriented Architecture - Revolutionizing today's banking systems. IBM Global Business Services. Available: www935.ibm.com/services/multimedia/SOA.pdf.

[5] Dalal Aljebry, Rizwan Qureshi,"Proposal to Improve Mobility in Service Oriented Architecture", International
Journal of Education and Management Engineering(IJEME), Vol.7, No.1, pp.14-24, 2017.DOI: 10.5815/ijeme.2017.01.02

[6] Zakaria Saleh, Rand Obeidat, Yaser Khamayseh,"A Framework for an E-government Based on Service Oriented Architecture for Jordan", International Journal of Information Engineering and Electronic Business(IJIEEB), DOI:10.5815/ijieeb.2013.03.01

[7] Pawan Kumar, Ratneshwer,"Some Observations on Dependency Analysis of SOA Based Systems", International Journal of Information Technology and Computer Science(IJITCS), DOI: 10.5815/ijitcs.2016.01.07

[8] S. Basu, F. Casati, and F. Daniel, "Toward web service dependency discovery for SOA management", in Proceedings of IEEE International Conference on Services Computing, DOI: 10.1109/SCC.2008.45, 2008, Vol. 2 pp. 422-429.

[9] Quist-Aphetsi Kester, Koumadi Koudjo M, Nii.Narku Quaynor,'Integration of Independent Applications and EAI Systems using Service Oriented Enterprise Bus and Open System Application Development Standards", International Journal of Information Technology and Computer Science(IJITCS), DOI: 10.5815/ijitcs.2013.07.01

[10] A. Meligy, Emad Elabd, Sahar Kotb,"Web Services Privacy Preserving Based on Negotiation and Certificate Authorities", International Journal of Modern Education and Computer Science (IJMECS), Vol.8, No.10, pp.49-55, 2016.DOI: $10.5815 /$ ijmecs.2016.10.07

[11] Annamalai, C., \& Ramani, A. V. (2015). Critical Success Factors (CSFs) of Service- Oriented Architecture (SOA) in BIG DATA Systems. International Journal of Research in Management, Science \& Technology, 3(3), 23-27.

[12] Karen Avila, Paul Sanmartin, Daladier Jabba, Miguel Jimeno, "Applications Based on Service-Oriented Architecture (SOA) in the Field of Home Healthcare". 2017. DOI: 10.3390/s17081703. Available Online: http://creativecommons.org/licenses/by/4.0/

[13] Erik-Jan Monshouwer, Raul Valverde,"Architecture for Integration of Point of Sale Terminals with Financial 
Institutions Through Web Service", Journal of Theoretical and Applied Information Technology (JATIT), 15th March 2011 Vol. 25 No.1

[14] Adji Sukmana, Mihuandayani et.al, "Design Concepts Smartcoop with Implementing Financial Technology", 2017 5th International Conference on Cyber and IT Service

Management(CITSM),DOI:10.1109/CITSM.2017.808927 9

[15] Thomas F. Dapp, 2014 November 11, Deutsche Bank Research, Fintech the Digital Revolution in the Financial Sector.

[16] Papazoglou, M.P., and Georgakopoulos, D. (2003), Service Oriented Computing: Introduction, Communications of the ACM, 46(10), pp. 25-28

[17] Arsanjani, A. Service-Oriented Modeling, and Architecture.Available:https://www.ibm.com/developerw orks/library/ws-soa-design1/ (accessed on 25 October 2017).

[18] Tsai, W.-T.; Fan, C.; Chen, Y.; Paul, R.A.; Chung, J.-Y. Architecture Classification for SOA-Based Applications. In Proceedings of the Ninth IEEE International Symposium on Object and Component-Oriented RealTime Distributed Computing (ISORC'06), Gyeongju, Korea, 24-26 April 2006; pp. 1-8

[19] Hofer, T.; Schumacher, M.; Bromuri, S. Compass: An Interoperable Personal Health System to Monitor and Compress Signals in Chronic Obstructive Pulmonary Disease. In Proceedings of the 2015 9th International Conference on Pervasive Computing Technologies for Healthcare (PervasiveHealth), Istanbul, Turkey, 20-23 May 2015; pp. 304-311

\section{Authors' Profiles}

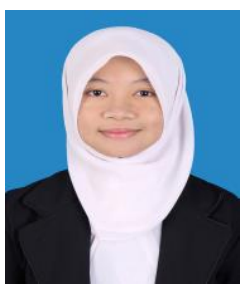

Mihuandayani was born in Molinow on September 20, 1995. She received her bachelor degrees from Universitas Amikom Yogyakarta, Indonesia in 2016. Now, she has been studying for her master degrees in Information Engineering, Universitas Amikom Yogyakarta. Since August 2016, she has been working as an assistant of Quality Assurance, Software Development in PT.
Time Excelindo. Her research interests include financial technology, data mining, decision support system and artificial intelligence.

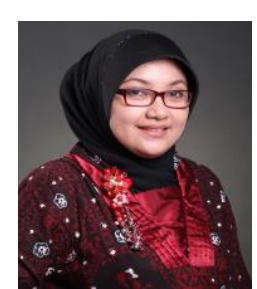

Ema Utami was born in Lampung, on February 21, 1975. She received bachelor, master and doctoral degrees in computer science from Universitas Gadjah Mada, Yogyakarta, Indonesia in 1997, 2002 and 2010 respectively. Since 1998 she has been a lecturer and researcher in Universitas Amikom Yogyakarta. Since 2010 she has been a vice director in magister of informatics engineering in Universitas Amikom Yogyakarta. She has written more than 15 computer science related books and published nationally. Prof. Dr. Ema Utami, S.Si, M.Kom is a member of several professional societies such as IEEE, IAENG, MASTEL and also as secretary general of national professional societies, IndoCEISS. Her current researches interest area are natural language processing, intelligent systems, computer algorithms and database programming.

How to cite this paper: Mihuandayani, Ema Utami," Design Concept Integration Tax Payment System with Implementing Financial Technology", International Journal of Information Engineering and Electronic Business(IJIEEB), Vol.10, No.5, pp. 15-22, 2018. DOI: 10.5815/ijieeb.2018.05.03 